\title{
INCREASING PRODUCTIVITY OF AN INTENSIVE RICE BASED SYSTEM THROUGH SITE SPECIFIC NUTRIENT MANAGEMENT IN WESTERN TERAI OF NEPAL
}

Santosh Marahatta ${ }^{1}$

\begin{abstract}
Improving nutrient management through site specific nutrient management (SSNM) can increase grain yield and maintain appropriate yield attributes per unit of fertilizer applied through harmonized uptake, utilization and metabolism of major nutrients. On-farm experiments were conducted from 2011-2013 at Sunawal, Nawalparasi. SSNM dose was calculated by accounting for indigenous nutrient supply, yield goal, nutrient demand and fertilizer efficiency. SSNM decreased nitrogen and phosphorus application by 4 and $28 \%$ while demanded $80 \%$ more potassium and increased grain yield by $6 \%$ over recommended practice. As compared to the farmers fertility management practice (FFP), SSNM increased grain yield by $35 \%$. Reducing $25 \%$ of SSNM dose was equally effective as recommended practice of nutrient application. Only improving the potassium application $\left(+32 \mathrm{~kg} \mathrm{ha}^{-1}\right)$ on FFP, yield was increased by $17 \%$. Leaf color charts (LCC) improve nitrogen management and proved as crucial component of SSNM as $0.3 t h^{-1}$ more yield over three split nitrogen applications of SSNM dose.
\end{abstract}

Key Words: Indigenous nutrient supply, Nitrogen use, Nutrient uptake, Site-specific nutrient management

\section{INTRODUCTION}

Food security of Nepal is threatened by the stagnating the yield of staple crops especially the rice. The average yield of rice in Nepal is very low $\left(3.2 \mathrm{t} \mathrm{ha}^{-1}\right)$ (FAOSTAT, 2016) as compared to potential yield $\left(8.0 \mathrm{t} \mathrm{ha}^{-1}\right)$ (Devkota et al., forthcoming). The green revolution technology increased the rice yield by $1.6 \%$ per annum from 1970 to 1990 (FAOSTAT, 2012) but stagnating there after (Ladha, 2003). At present, the productivity and sustainability of rice based systems are threatened by inefficient use of agro-inputs; decline in soil fertility and loss of soil organic matter; increasing scarcity of resources, especially irrigation water and labor; changing climate; rising cost of cultivation and socioeconomic changes such as urbanization, migration of labor, preference of nonagricultural works. Identifying the process governing the sustainability of rice based system is crucial for developing the sustainable agronomic management and technological innovations.

Nutrient balance, which describes nutrient stock and flows in specific farming systems are powerful tools in determining the present and future productivity of agricultural lands as well as undesirable environmental effects such as nutrient mining or pollution of surface and ground water. Quantification of the soil's capacity for supplying N, P and K is essential to predict the additional requirement of nutrients and improving nutrient use efficiencies. On farm trails demonstrated that indigenous supply of N, P and K was highly variable among farms (Adhikari et al., 1999). Therefore, a new concept SSNM in rice based systems is being developed (Dobermann and White, 1999). In SSNM approach, scientists quantify crop nutrient requirement based on an economically efficient yield target; measure the potential indigenous supply of $\mathrm{N}, \mathrm{P}$ and $\mathrm{K}$; estimate the $\mathrm{P}$ and $\mathrm{K}$ balance for sustaining soil $\mathrm{P}$ and $\mathrm{K}$ reserves without depletion; monitor plant $\mathrm{N}$ status during critical period of rice growth to optimized fertilizer $\mathrm{N}$ efficiency and apply diagnostic criteria for identifying micronutrient disorders (Dobermann and White, 1999).

SSNM is a low-tech, plant need-based approach for optimally applying mainly major nutrients $N, P$, and $\mathrm{K}$ (IRRI, 2006). It enables farmers to dynamically adjust fertilizer use to fulfill the deficit 
between the crop nutrient needs and the nutrient supply from natural sources (Pampolino et al., 2007). The SSNM approach aims to apply nutrients at optimal rates and times to achieve high yields and high efficiency of nutrient use by the crop. It does not specifically aim to either reduce or increase fertilizer use (Buresh et al., 2005) as it is based on nutrient supplying capacity and fertilizers required for certain target yields. In addition to soil variability and nutrient management practices, crop management has a significant role in utilization of the inherent and applied nutrients. Viewing these facts, the present study was conducted to formulate the site specific nutrient management strategies for rice to improve the present yield growth for intensive rice based system.

\section{MATERIALS AND METHOD}

\section{EXPERIMENTAL SITE}

The experiments were conducted in the farmers' fields of Sunawal in Nawalparasi District (representing inner terai) during the rainy season of 2011, 2012 and 2013 from June to November. The site is located $22 \mathrm{~km}$ east from the business city Butawal, Rupendehi. This location is situated at $27^{\circ} 36^{\prime} \mathrm{N}$ latitude and $83^{\circ} 38^{\prime} \mathrm{E}$ longitude. Soil texture varied from sandy loam to clay loam. The area has a subtropical climate highly influenced by the southern monsoon. Those farmers' who adopted the rice based farming system were selected randomly varied on soil physical and chemical characters.

\section{PHYSIO-CHEMICAL PROPERTIES OF EXPERIMENTAL SOIL}

Composite soil sample were randomly taken from different spots from $0-15 \mathrm{~cm}$ depth using tube auger to record the initial soil physico-chemical properties of the experimental site. Soil sample was air dried, grounded and sieved through $2 \mathrm{~mm}$ sieve and tested for their properties. The total nitrogen was determined by Kjeldhal distillation unit, available phosphorus by modified Olsen's method by using spectrophotometer and available potassium by ammonium acetate method (Estefan et al., 2013). Organic matter was determined by Walkey and Black method, pH (1:1 soil: water suspensions) by Beckman Glass Electrode $\mathrm{pH}$ meter and soil texture by hydrometer method (Estefan et al., 2013). Physico-chemical properties of the soil of the experimental farmers' field are presented in Table 1. From the analysis, soils of the experimental sites were varied largely among the farmers' field. Soil pH that affects the availability of mineral nutrients varied from 6.31 to 7.56 with the average of 7.06 . The total carbon and nitrogen ranged from 0.54 to $0.84 \%$ and 0.057 to $0.117 \%$ respectively with the average of 0.70 and 0.086 percent. Available $\mathrm{P}$ and $\mathrm{K}$ also varied greatly among the farmers' field but both these micronutrients were in medium availability on an average. Soil texture varied among the field from sandy loam to clay loam. The percent of sand, silt and clay ranged from 37 to $54 \%, 24$ to $43 \%$ and 16 to $25 \%$ respectively.

Table 1. Physico-chemical properties of the soil $(0-15 \mathrm{~cm})$ before start of experiments at Sunawal, Nawalparasi, Nepal, 2013

\begin{tabular}{clllllllll}
\hline $\begin{array}{c}\text { Farm } \\
\#\end{array}$ & $\begin{array}{l}\text { Sand } \\
(\%)\end{array}$ & $\begin{array}{l}\text { Silt } \\
(\%)\end{array}$ & $\begin{array}{l}\text { Clay } \\
(\%)\end{array}$ & Texture & $\begin{array}{l}\text { Soil } \\
\mathbf{p H}\end{array}$ & $\begin{array}{l}\text { Organic } \\
\mathbf{C}(\%)\end{array}$ & $\begin{array}{l}\text { Total } \\
\mathbf{N}(\%)\end{array}$ & $\begin{array}{l}\text { Available P } \\
\left(\mathbf{k g ~ h a}^{-1}\right)\end{array}$ & $\begin{array}{l}\text { Available K } \\
\left(\mathbf{k g ~ h a} \mathbf{~}^{-1}\right)\end{array}$ \\
\hline 1 & 51.00 & 21.00 & 28.00 & Loam & 6.31 & 0.79 & 0.089 & 58.00 & 163.54 \\
2 & 37.00 & 20.00 & 43.00 & Loam & 7.56 & 0.84 & 0.089 & 48.00 & 98.47 \\
3 & 41.00 & 31.00 & 28.00 & Clay loam & 7.07 & 0.63 & 0.066 & 37.00 & 115.00 \\
4 & 54.00 & 16.00 & 30.00 & Sandy loam & 7.27 & 0.54 & 0.068 & 47.00 & 111.97 \\
\hline 5 & 53.00 & 21.00 & 26.00 & $\begin{array}{l}\text { Sandy clay } \\
\text { loam }\end{array}$ & 6.33 & 0.68 & 0.117 & 32.00 & 84.96
\end{tabular}




\begin{tabular}{llllllllll}
6 & 40.00 & 25.00 & 35.00 & Loam & 7.42 & 0.83 & 0.080 & 43.00 & 143.23 \\
7 & 52.00 & 24.00 & 24.00 & $\begin{array}{l}\text { Sandy clay } \\
\text { loam }\end{array}$ & 7.44 & 0.63 & 0.057 & 24.00 & 98.47 \\
Mean & 46.86 & 22.57 & 30.57 & Loam & 7.06 & 0.70 & 0.086 & 41.29 & 116.52 \\
\hline
\end{tabular}

\section{CLIMATIC CONDITION DURING EXPERIMENTATION}

The experimental site lies in the subtropical humid climate belt of Nepal. The metrological data for cropping season of 2013 was recorded from the metrological station of National Wheat Research Program (NWRP), Bhairahawa, Rupendehi about $25 \mathrm{~km}$ far from the research site (Figure 1). The total rainfall of $2406.86 \mathrm{~mm}$ was received during the entire period of experimentation whereas 1954 $\mathrm{mm}$ of rainfall was recorded in the rice growing period (after transplanting, $2^{\text {nd }}$ week of July to harvesting, $4^{\text {th }}$ week of October). The highest rainfall was recorded during August $(895 \mathrm{~mm})$ and minimum rainfall in a month of October $(135 \mathrm{~mm})$ of crop growth period. First three months of rice growing period, the crop received more or less uniformly distributed rainfall with a monthly average not less than $400 \mathrm{~mm}$. Sharma et al. (1991) also recorded that rainfall of $1250 \mathrm{~mm}$ was required for vegetative growth of rice. The mean maximum temperature during the experimental period ranged from $24.20^{\circ} \mathrm{C}$ to $38.20^{\circ} \mathrm{C}$ during experimentation period. It was the highest during July and the lowest during October. Similarly, the mean minimum temperature during cropping period ranges from $20.00^{\circ} \mathrm{C}$ to $30.00^{\circ} \mathrm{C}$. It was the highest during June and the lowest during October.

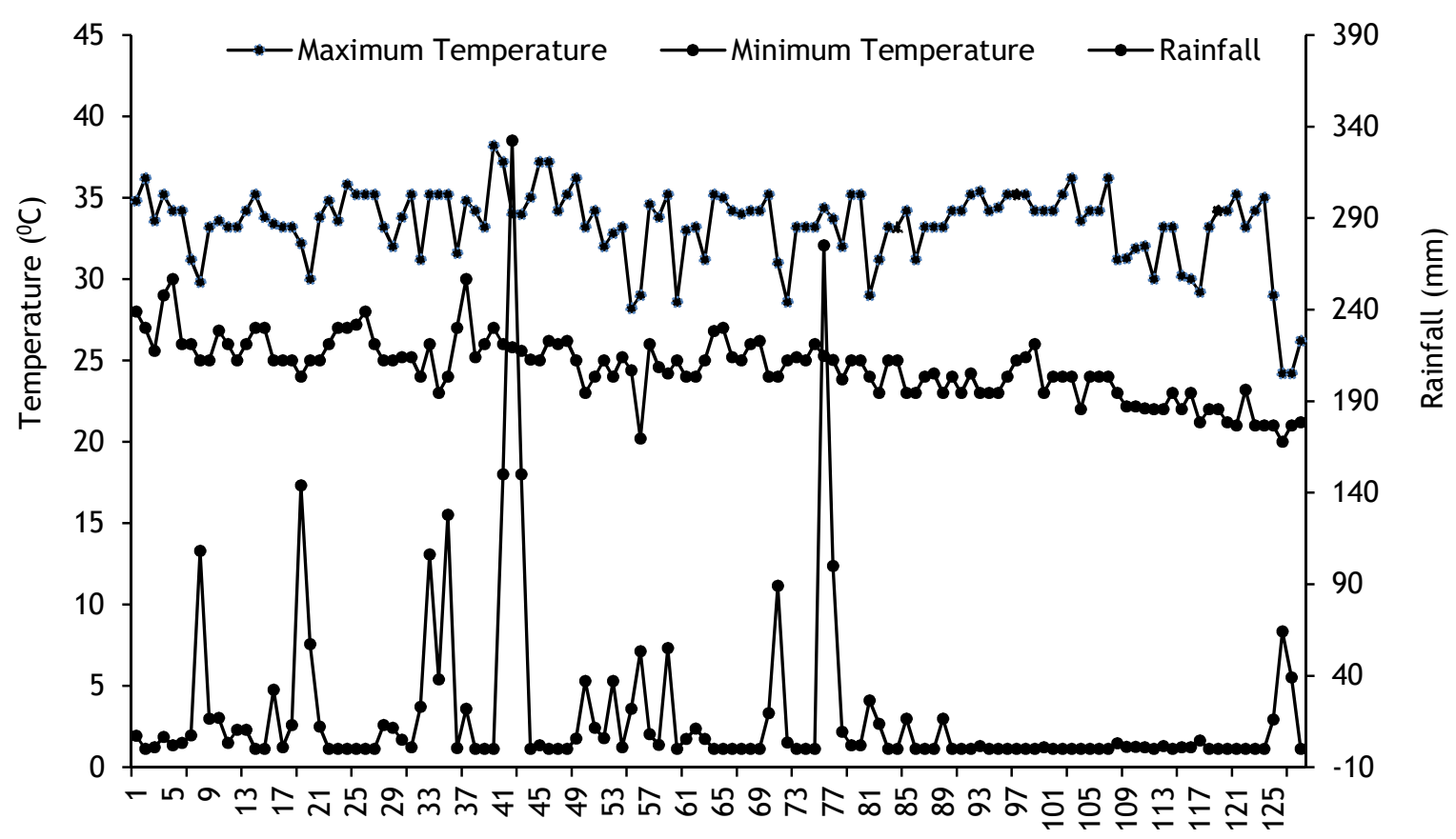

Days after sowing

Figure 1.Weather condition during the experimentation period at Sunwal, Nawalparasi, Nepal from 22 June to 31 October 2013. 


\section{EXPERIMENTAL DETAILS: LAYOUT AND TREATMENT}

The experiments were conducted in farmers' fields from 2011-13. In 2011 and 2012, the indigenous nutrient supplying capacity was determined from farmers' field by omission plot experiments with 6 treatments namely nitrogen omission ( $\mathrm{ON}+$ ample of $\mathrm{PK})$, phosphorus omission (OP+ample of NK), potassium omission (OK+ample NP), recommended NPK (100:60:40 kg NPK ha ${ }^{-1}$ ), FFP (different among farmers) and ample NPK (150\% of recommended dose) on 36 farmers' field. Site-specific nutrient management experiments (Table 2) was conducted in 7 representative farmers' field in 2013. The plot size was $20-60 \mathrm{~m}^{2}$ depending upon the farmers field and each filed was considered as one replication. All treatments were accommodated in the same fields that receive farmers' management on fertility in preceding crops. Plots (treatments) were separated by bunds to check any over flow of nutrient through water from one to another.

Table 2. Details of treatments in experiment during June to November 2013 at Sunawal, Nawalparasi, Nepal

\begin{tabular}{|c|c|c|c|}
\hline SN & Treatments & $\mathrm{N}, \mathrm{P}_{2} \mathrm{O}_{5}$ and $\mathrm{K}_{2} \mathrm{O}$ dose $\left(\mathrm{kg} \mathrm{ha}^{-1}\right)$ & Symbol \\
\hline 1 & SSNM $^{*}$ at yield target at $7.0 \mathrm{t} \mathrm{ha}^{-1}$ & $95.82+42.98+72.00$ & $\mathrm{~T}_{1}$ \\
\hline 2 & $75 \%$ of $\mathrm{SSNM}^{*}$ dose at yield target at $7.0 \mathrm{t} \mathrm{ha}^{-1}$ & $71.86+32.23+54.00$ & $\mathrm{~T}_{2}$ \\
\hline 3 & SSNM P \& K, LCC based N application ${ }^{* *}$ & $N+42.98+72.00$ & $\mathrm{~T}_{3}$ \\
\hline 4 & Farmers' fertility management practices ${ }^{* * *}$ & $52.50+25.91+8.30$ & $\mathrm{~T}_{4}$ \\
\hline 5 & Farmers dose of $\mathrm{N}$ and $\mathrm{P}, \mathrm{Rec}$. dose of $\mathrm{K}$ & $52.50+25.91+40.00$ & $T_{5}$ \\
\hline 6 & Recommended doseף & $100.00+60.00+40.00$ & $\mathrm{~T}_{6}$ \\
\hline
\end{tabular}

Notes:

Phosphorus (from DAP, $18 \% \mathrm{~N}$ and $46 \% \mathrm{P}_{2} \mathrm{O}_{5}$ ) and potash (from MOP, $60 \% \mathrm{~K}_{2} \mathrm{O}$ ) was applied as basal dose in all treatments. Nitrogen was applied from Urea $(46 \% \mathrm{~N})$ in all plots.

* SSNM dose was calculated on yield target of $7 \mathrm{t} \mathrm{ha}^{-1}$. In SSNM and 75\% of SSNM treatments, $1 / 2 \mathrm{~N}$ was applied as basal and $1 / 2 \mathrm{~N}$ applied at tillering and PI as two equal split.

** In LCC based $\mathrm{N}$ application, 1/4th of recommend dose $\mathrm{N}\left(25 \mathrm{~kg} \mathrm{ha}^{-1}\right)$ was applied as basal dose. The remaining nitrogen will be top dressed as LCC reading $<4$ with $20 \mathrm{~kg} \mathrm{~N} \mathrm{ha}^{-1}$.

${ }^{* * *}$ Fertilizer dose on farmers' fertility management practices was calculated on the basis of farmers' survey in 2012 from 42 households. $1 / 3^{\text {rd }} \mathrm{N}\left(17.50 \mathrm{~kg} \mathrm{ha}^{-1}\right)$ was applied as basal and remaining $2 / 3^{\text {rd }} \mathrm{N}\left(35 \mathrm{~kg} \mathrm{ha}^{-1}\right)$ applied at tillering and $\mathrm{PI}$ as two equal split.

If $1 / 2 \mathrm{~N}$ was applied as basal and $1 / 2 \mathrm{~N}$ applied at tillering and PI as two equal split.

\section{CALCULATION OF SSNM DOSE}

Estimation of target yield:The mean simulated $\mathrm{Y}_{\max }$ of current rice varieties grown in inner terai of Nepal is around 8.87-9.47 $\mathrm{t} \mathrm{ha}^{-1}$ in main season, with a mean of 9.08 (Regmi, 2003). The target yield is around $75-80 \%$ of the potential yield (Witt et al., 1999). So, $7 \mathrm{t} \mathrm{ha}^{-1}$ was considered as the target yield for this study.

Estimating nutrient requirements to get the target yield:In order to get a target yield of $7 \mathrm{t} \mathrm{ha}^{-1}$ rice plants must be sullied with $102.90 \mathrm{~kg} \mathrm{~N}, 41.70 \mathrm{~kg} \mathrm{P}_{2} \mathrm{O}_{5}$ and $122.27 \mathrm{~kg} \mathrm{~K}_{2} \mathrm{O}$.

Estimating indigenous nutrient supply from soils: Indigenous nutrient defined as nutrients that crop uptake and accumulate to produce grain yield in the plots without fertilizer application. To determine indigenous nitrogen supply from soil omission plot experiments were conducted during $2011(n=19)$ and $2012(n=17)$, in which no anymore nitrogen fertilizer is added to the plots but the 
ample application of $\mathrm{P}$ and $\mathrm{K}$ (150\% of recommended dose). The contribution of nitrogen to produce grain yield in this plot is called indigenous nitrogen and the similar cases for phosphorus and potassium. The mean of grain yield in the omission plots for nitrogen was $3.74 \mathrm{t} \mathrm{ha}^{-1}$ and then the amount of nitrogen supply from soils as $54.99 \mathrm{~kg} \mathrm{~N} \mathrm{ha}^{-1}$. Similarly, the yield in omission plots for phosphorus is $4.84 \mathrm{t} \mathrm{ha}^{-1}$ and then the amounts of phosphorus supply from soils as $28.81 \mathrm{~kg} \mathrm{P}_{2} \mathrm{O}_{5} \mathrm{ha}^{-1}$. Again, grain yield in omission plots for potassium is $4.94 \mathrm{t} \mathrm{ha}^{-1}$ and then the amounts of potassium supply from soils as $86.27 \mathrm{~kg} \mathrm{~K}_{2} \mathrm{O} \mathrm{ha}^{-1}$.

Calculating fertilizer requirements: Nutrient requirement is defined as the amounts of nutrients needed by a crop for producing the target yield minus the amounts of indigenous nutrient (soils and other sources). While fertilizer recovery (\%) was the percentages of nutrients absorbed by a crop out of the total amounts of fertilizers applied. Suppose the amounts of nutrients come from other sources are small, then the nutrient requirements were calculated as:

$$
\begin{array}{lll}
\text { Nitrogen requirements: } & 102.90-54.99=47.91 \mathrm{~kg} \mathrm{~N} \mathrm{ha}^{-1} \\
\text { Phosphorus requirements: } & 41.70-28.81=12.89 \mathrm{~kg} \mathrm{P}_{2} \mathrm{O}_{5} \mathrm{ha}^{-1} \\
\text { Potassium requirements: } & 122.27-86.27=36.00 \mathrm{~kg} \mathrm{~K}_{2} \mathrm{O} \mathrm{ha}^{-1}
\end{array}
$$

Fertilizer recovery (\%) for nitrogen in 2012 was $45-50 \%, 25-30 \%$ for phosphorus and $40-50 \%$ for potassium. Thus, the amounts of nutrient required to apply in was calculated by the following formula and result in SSNM dose of $95.82 \mathrm{~kg} \mathrm{~N} \mathrm{ha}^{-1}, 42.98 \mathrm{~kg} \mathrm{P}_{2} \mathrm{O}_{5} \mathrm{ha}^{-1}$ and $72.00 \mathrm{~kg} \mathrm{~K}_{2} \mathrm{O} \mathrm{ha}^{-1}$.

The amounts of nutrient required

$$
\begin{aligned}
& =\left(\frac{\text { Nutrietn requiremnet } \times 10}{\text { FR of Nutrient }}\right) \\
& =95.82 \mathrm{~kg} \mathrm{~N} \mathrm{ha}^{-1} \\
& =42.98 \mathrm{~kg} \mathrm{P}_{2} \mathrm{O}_{5} \mathrm{ha}^{-1} \\
& =72.00 \mathrm{~kg} \mathrm{~K}_{2} \mathrm{O} \mathrm{ha}^{-1}
\end{aligned}
$$

\section{CULTIVATION PRACTICES}

Wet bed nursery were prepared and seedlings of 22-26 days were transplanted on well prepared puddled fieldwith three seedlings per hill maintaining $20 \mathrm{~cm} \times 20 \mathrm{~cm}$ row to row and plant to plant distance. Gap fillings were done after a week of rice transplanting in some plots to maintain the desired plant population. The doses of fertilizers were applied as accordance to treatments (Table 2 ). Two hand weeding were done in the plots to reduce the competition between weeds and crop for nutrients at 20 days and 45 days after transplanting. Two to six irrigations were given in the field as per requirement that depends upon the individual farmers' field. About $5 \mathrm{~cm}$ water was maintained either through irrigation pump or channel irrigation regularly up to grain filling stage of rice crop. The crop from the net plot area $\left(12 \mathrm{~m}^{2}\right)$ was harvested manually with the help of sickles. Harvested plants were left in-situ in the field for 3 days for sun drying. Threshing was done with mini thresher and grains thus obtained were cleaned by winnowing and weighted at their exact moisture.

\section{PROXIMATE COMPOSITION AND NUTRIENT ANALYSIS OF PLANT SAMPLE}

Grain samples were oven dried at $65^{\circ} \mathrm{C}$ for five to seven days. Representative of subsamples of straw (200-300 g) were taken immediately after weighing the total fresh weight to avoid the moisture loss. The subsamples are also oven dried $65^{\circ} \mathrm{C}$ for five to seven days and oven dry weight of samples was calculated. Both oven dried samples of grain and straw were ground using grinder machine and kept in brown paper bag until nutrient analysis. For estimating total nitrogen content, leaf and grain 
samples were digested with concentrated sulphuric acid and digestion mixture in micro Kjeldahl's assembly. For phosphorus and potassium determination, straw and grain samples were digested with diacid mixture $\left(\mathrm{HNO}_{3}: \mathrm{HClO}_{4}\right.$ in 10: 4 ratio), after predigesting with concentrated nitric acid, till colorless white precipitate is obtained. The precipitate was then dissolved in $6 \mathrm{~N} \mathrm{HCl}$ and filtered and filtrate was made up to $100 \mathrm{ml}$ using distilled water.

\section{OBSERVATION RECORDED}

Leaf color chart (LCC) reading: For $\mathrm{N}$ top dressing under real time nitrogen application treatments, LCC reading was taken at an interval of 10 days on fixed 10 plants from 14 days after transplanting (DAT) to the beginning of flowering in each replication. Readings were taken on the top most fully expanded leaf of randomly selected fixed 10 disease free plants by placing its middle part on top of the color strips in the chart. If six or more leaves read bellow a set critical value (4), predetermined rate of $\mathrm{N}$ was applied as $20 \mathrm{~kg} \mathrm{~N} \mathrm{ha}^{-1}$.

Yield attributing characters of rice: Effective tillers per square meter, length of panicle, grains per panicles, sterility percentage and thousands grain weight were recorded.

Biomass yield, grain yield and harvest index: Biomass yield, straw yield and grain yield were taken at harvesting from net plot of $12 \mathrm{~m}^{2}$ area. The crop was dried, threshed, sun dried; cleaned and final weight was taken. The grain yield per hectare was computed form each treatment from the net plot yield. The moisture percentage of grains was recorded from the moisture meter (Model: Willy 55$)$. Finally grain yield was adjusted at $14 \%$ moisture using the formula as

Gain yield $\left(\mathrm{Kg} \mathrm{ha}^{-1}\right)$ at $14 \%$ moisture $=\frac{(100-\mathrm{M}) \times \text { plot yield }(\mathrm{kg}) \times 10000\left(\mathrm{~m}^{2}\right)}{(100-14) \times \text { net plot area }\left(\mathrm{m}^{2}\right)}$

Where, $M C$ is the moisture content in percentage of the grains.

Straw yield was also recorded from the rows of net plot and then translated into hectare. Harvest index $(\mathrm{HI})$ was computed by dividing grain yield with the total dry matter yield as per the following formula.

$$
\text { H.I. \% }=(\text { grain yield } \times 100) /(\text { grain yield }+ \text { straw yield })
$$

Yield gap calculation:Three types of yield gap were calculated. The yield gap I is the difference between maximums attainable yield ( $80 \%$ of the climatic yield) and the SSNM yield at first yield target in farmers' field. The second gap (Yield gap II) is the difference between attainable yield and FFP in farmers' field. The third yield gap (Yield gap III) is the difference between the SSNM yield at first yield target and yield obtained in FFP in farmers' field.

Nutrient uptake:Grain and straw nutrient uptake were calculated as

Nutrient uptake in grain $=\left(\frac{\text { Nutrient Concentration in grain } \times \text { Oven dry weight of grain }}{100}\right)$
Nutrient uptake in Straw $=\left(\frac{\text { Nutrient Concentration in Straw } \times \text { Oven dry weight of straw }}{100}\right)$

Total nutrient uptake $(T N U)=$ Nutrient uptake in grain + Nutrient uptake in Straw

\section{STATISTICAL PROCEDURE}

Analyses of variance (ANOVA) of the recoded parameters were performed in randomized complete block design (RCBD) considering each farmer as a replication. Means were separated by Duncan's Multiple Range Test (DMRT) at 0.05 level of significance. A simple correlation and regression analysis 
was run between selected parameters. Regarding the software programs, Microsoft word 2007 was used for word processing, MS excels for tables, graphs, and GenStat-15 and SPSS-16 computer programs were used for running statistical analysis.

\section{RESULTS AND DISCUSSION}

\section{EFFECT OF NUTRIENT MANAGEMENT ON YIELD ATTRIBUTES AND CROP YIELD}

Nutrient management practices had significant effect on the grain and straw yield (Table 3 ). Application of LCC-N + SSNM-P \& K had produced significantly higher grain yield than other nutrient management practices except SSNM. SSNM had also produced significantly higher yield than farmers' nutrient management practice implies the lack of nutrient input in farmer's practices. It clearly indicated that farmers' yield could be increased by proper nutrient management. Farmers generally applied nitrogenous $\left(52.50 \mathrm{~kg} \mathrm{ha}^{-1}\right)$ and small amount of phosphorus $\left(25.91 \mathrm{~kg} \mathrm{ha}^{-1}\right)$. Only $47.22 \%$ farmers apply potassium with an average of $8.27 \mathrm{~kg} \mathrm{ha}^{-1}$ (based on survey of 36 farmers). Regmi et al. (2002) reported rice yield reduced in terai was due to lack of phosphorus and potassium. Significantly lower yield in the FFP suggests that the insufficient use of nutrient especially nitrogen by the farmers was one of the factors for low yield in farmers' field. In Nepal, crops are harvested close to the ground level and straw is removed from the field, thus recycling of potassium through the straw is negligible. So the potassium content of cereal crop field is very low. Thus the grain yield gap between FFP and FFP - N and P + Rec. $K$ could be attributed to the lack of $K$ in the farmers' field. Application of fertilizer at recommended dose had yielded similar yield to that of $75 \%$ SSNM that clearly indicate the saving of nutrients $\left(41.91 \mathrm{~kg} \mathrm{ha}^{-1}\right)$ with the help of balance application of nutrients and recommendation need to be revised.

Table 3: Effect of nutrient management on yield and yield attributes of rice at Sunawal, Nawalparasi district, Nepal, 2013

\begin{tabular}{|c|c|c|c|c|c|c|c|}
\hline Treatments & $\begin{array}{c}\text { Grain yield } \\
\left(\mathrm{t} \mathrm{ha}^{-1}\right)\end{array}$ & $\begin{array}{c}\text { Straw yield } \\
(\mathrm{t} \mathrm{ha-1)}\end{array}$ & HI (\%) & $\begin{array}{c}\text { ET per } \\
\mathrm{m}^{2}\end{array}$ & $\begin{array}{c}\text { Grains per } \\
\text { panicle }\end{array}$ & $\begin{array}{l}\text { TGW } \\
\text { (g) }\end{array}$ & $\begin{array}{c}\text { Sterility } \\
(\%)\end{array}$ \\
\hline SSNM & $6.35^{\mathrm{ab}}$ & $5.89^{a}$ & 48.13 & $277.14^{\mathrm{ab}}$ & 100.58 & $24.98^{a}$ & $15.61^{b}$ \\
\hline $75 \%$ SSNM dose & $5.88^{\mathrm{bc}}$ & $5.71^{\mathrm{a}}$ & 47.18 & $263.64^{\mathrm{ab}}$ & 98.76 & $24.90^{\mathrm{a}}$ & $16.36^{\mathrm{b}}$ \\
\hline LCC-N and SSNM-P \& K & $6.66^{\mathrm{a}}$ & $5.98^{\mathrm{a}}$ & 48.98 & $280.29^{a}$ & 102.76 & $25.36^{a}$ & $13.36^{c}$ \\
\hline FFP & $4.62^{d}$ & $4.71^{\mathrm{b}}$ & 45.62 & $224.86^{\mathrm{C}}$ & 94.94 & $24.26^{\mathrm{bc}}$ & $18.07^{a}$ \\
\hline Rec. $\mathrm{K}$ and FFP $\mathrm{N}$ and $\mathrm{P}$ & $5.41^{\mathrm{c}}$ & $5.26^{\mathrm{ab}}$ & 46.59 & $252.14^{b}$ & 99.17 & $24.04^{\mathrm{a}}$ & $16.76^{\mathrm{ab}}$ \\
\hline Rec. NPK & $5.90^{\mathrm{bc}}$ & $5.58^{\mathrm{a}}$ & 47.84 & $269.74^{\mathrm{ab}}$ & 96.98 & $24.83^{\mathrm{ab}}$ & $15.85^{b}$ \\
\hline SEm ( \pm$)$ & 0.16 & 0.23 & 1.19 & 8.31 & 3.49 & 0.20 & 0.52 \\
\hline LSD (=0.05) & 0.48 & 0.66 & $3.43^{\text {ns }}$ & 24.01 & $10.08^{\mathrm{ns}}$ & 0.59 & 1.51 \\
\hline $\mathrm{CV}, \%$ & 7.50 & 11.02 & 6.63 & 8.42 & 9.34 & 2.18 & 8.66 \\
\hline Grand mean & 5.80 & 5.52 & 47.39 & 261.30 & 98.87 & 24.73 & 16.00 \\
\hline
\end{tabular}

ns, non significant. HI, harvest index; ET, effective tillers; TGW, thousand grains weight; SSNM, site specific nutrient management; LCC, leaf color chart; FFP, farmers fertility practice, Rec., Recommended. Means in the column followed by the same letter(s) are not significant different by DMRT at 0.05 level of significance.

Effective tillers per square meter, thousand grains weight and sterility percentages were significantly influenced by the fertility management practices but grains per panicle was not (Table 3). LCC-N + SSNM - P \& $K$ had highest effective tillers per square meter which was significantly higher than the FFP and farmers' $\mathrm{N}$ and $\mathrm{P}+\mathrm{rec} . \mathrm{K}$ applied treatments but statistically at par with SSNM, 75\% SSNM and recommended NPK (Table 3). Lowest effective tillers were observed in the FFP. A significant correlation $\left(r=0.80^{* *}\right)$ was found between tillers per square meter and grain yield 
(Table 4). In the experiment, highest number of grains per panicle and thousand grain weight were observed in LCC-N + SSNM - P \& K followed by SSNM (Table 3). There was significant correlation $\left(r=0.53^{* *}\right)$ between grains per panicle and grain yield (Table 4$)$. Significantly lowest sterility was observed in LCC-N + SSNM- P \& K treatment than all other treatments (Table 3). Nitrogen stress during heading and flowering had significantly increased the sterility in lower $\mathrm{N}$ applied treatments like FFP and FFP- N and P + Rec. K. Sterility percentage had significantly reduced $\left(r=-0.41^{* *}\right)$ the grain yield (Table 4$)$.

The highest straw yield is obtained in the LCC -N + SSNM - P \& K applied plot which was significantly higher than the FFP but statistically similar to other treatments (Table 3 ). Higher fertilizer input especially $\mathrm{K}$ in these treatments could be the possible reason for the higher straw yield. Nutrient management practice had not significant effect for the harvest index obtain. Comparatively higher harvest index was obtained in higher dose of nutrient applied plots and lowest in the farmer practice. Addition of potassium on the FFP increased the harvest index due to fully utilized $\mathrm{N}$ and $\mathrm{P}$ but in FFP, N and P were not fully utilized by the rice plant due to lack of K. Significant positive correlation $\left(r=0.46^{* *}\right)$ was found between the harvest index and grain yield (Table 4).

Table 4: Correlation analysis between yield and different yield components of rice in nutrient management at Sunawal, Nawalparasi, Nepal, 2013

\begin{tabular}{|c|c|c|c|c|c|c|}
\hline Parameters & GPP & TGW (g) & Sterility (\%) & $G Y\left(t h a^{-1}\right)$ & SY $\left(\mathrm{t} \mathrm{ha}^{-1}\right)$ & HI (\%) \\
\hline$\overline{E T} \mathrm{~m}^{-2}$ & $0.07^{\mathrm{ns}}$ & $0.114^{\mathrm{ns}}$ & $-0.236^{\mathrm{ns}}$ & $0.799^{* *}$ & $0.655^{* *}$ & $0.306^{*}$ \\
\hline GPP & & $-0.091^{\mathrm{ns}}$ & $-0.185^{\mathrm{ns}}$ & $0.532^{* *}$ & $0.532^{* *}$ & $0.119^{\text {ns }}$ \\
\hline TGW (g) & & & $-0.366^{*}$ & $0.250^{\text {ns }}$ & $0.078^{\text {ns }}$ & $0.243^{\text {ns }}$ \\
\hline Sterility (\%) & & & & $-0.409^{* *}$ & $-0.385^{*}$ & $-0.091^{\text {ns }}$ \\
\hline GY $\left(\mathrm{t} \mathrm{ha}^{-1}\right)$ & & & & & $0.777^{* *}$ & $0.464^{* *}$ \\
\hline$S Y\left(t h a^{-1}\right)$ & & & & & & $-0.186^{\mathrm{ns}}$ \\
\hline
\end{tabular}

ns, non-significant; * significant at $\mathrm{p}=0.05 ;{ }^{* *}$ significant at $\mathrm{p}=0.01$. ET, Effective tillers; GPP, Grains per panicle; TGW, Thousand grain weight; GY, Grain yield; SY, Straw yield; HI, Harvest index

\section{EFFECT OF NUTRIENT MANAGEMENT ON NUTRIENT UPTAKE}

The grain, straw and total $N, P$ and $K$ uptake were significantly differing among the fertility management practices (Table 5). Grain N uptake in LCC-N + SSNM-P \& $\mathrm{K}$ and SSNM was statistically at par and similar trend was observed in total $\mathrm{N}$ uptake. But statistically similar straw $\mathrm{N}$ uptake was in LCC-N + SSNM-P \& K, SSNM, 75\% SSNM and recommended NPK applied plots. Significantly lowest total $\mathrm{N}$ uptake was recorded in FFP indicating the lower fertilizer dose had reduced the total $\mathrm{N}$ uptake and hence grain yield. But application of recommended dose of $\mathrm{K}$ along with farmers $\mathrm{N}$ and $\mathrm{P}$ had significantly increased the grain, straw and total $N$ content over FFP because of better utilization of $\mathrm{N}$ in higher $\mathrm{K}$ level. $\mathrm{K}$ application enhances protein and amino acid content in grain crops due to optimum translocation of amino acids, nitrates and incorporation of $\mathrm{N}$ into protein (Koch and Mengel, 1974).

Table 5: Effect of nutrient management on rice nitrogen, phosphorus and potassium uptake (kg ha-1) at Sunawal, Nawalparasi, Nepal, 2013

\begin{tabular}{|c|c|c|c|c|c|c|c|c|c|}
\hline \multirow{2}{*}{ Treatments } & \multicolumn{3}{|c|}{$\mathrm{N}$ uptake $\left(\mathrm{kg} \mathrm{ha}^{-1}\right)$} & \multicolumn{3}{|c|}{$\mathrm{P}$ uptake $\left(\mathrm{kg} \mathrm{ha}^{-1}\right)$} & \multicolumn{3}{|c|}{ K uptake $\left(\mathrm{kg} \mathrm{ha}^{-1}\right)$} \\
\hline & Grain & Straw & Total & Grain & Straw & Total & Grain & Straw & Total \\
\hline SSNM & $63.91^{a}$ & $49.70^{a}$ & $113.62^{a}$ & $18.09^{b}$ & $8.47^{a}$ & $26.57^{\mathrm{ab}}$ & $16.04^{\mathrm{ab}}$ & $106.10^{\mathrm{ab}}$ & $122.14^{\mathrm{ab}}$ \\
\hline
\end{tabular}




\begin{tabular}{llllllllll}
$75 \%$ SSNM dose & $56.45^{\mathrm{b}}$ & $44.80^{\mathrm{ab}}$ & $101.25^{\mathrm{b}}$ & $17.37^{\mathrm{bc}}$ & $8.30^{\mathrm{a}}$ & $25.67^{\mathrm{bc}}$ & $14.77^{\mathrm{b}}$ & $93.92^{\mathrm{ab}}$ & $108.69^{\mathrm{b}}$ \\
LCC-N and SSNM-P \& K & $67.30^{\mathrm{a}}$ & $49.98^{\mathrm{a}}$ & $117.28^{\mathrm{a}}$ & $20.10^{\mathrm{a}}$ & $8.45^{\mathrm{a}}$ & $28.55^{\mathrm{a}}$ & $17.53^{\mathrm{a}}$ & $112.56^{\mathrm{a}}$ & $130.09^{\mathrm{a}}$ \\
FFP & $42.44^{\mathrm{c}}$ & $32.09^{\mathrm{c}}$ & $74.54^{\mathrm{c}}$ & $13.46^{\mathrm{d}}$ & $7.02^{\mathrm{b}}$ & $20.49^{\mathrm{d}}$ & $11.05^{\mathrm{d}}$ & $63.53^{\mathrm{c}}$ & $74.58^{\mathrm{c}}$ \\
Rec. K and FFP N and P & $53.43^{\mathrm{b}}$ & $40.65^{\mathrm{b}}$ & $94.09^{\mathrm{b}}$ & $15.90^{\mathrm{c}}$ & $7.75^{\mathrm{ab}}$ & $23.65^{\mathrm{c}}$ & $13.12^{\mathrm{c}}$ & $90.37^{\mathrm{b}}$ & $103.48^{\mathrm{b}}$ \\
Rec. NPK & $57.63^{\mathrm{b}}$ & $43.98^{\mathrm{ab}}$ & $101.61^{\mathrm{b}}$ & $18.23^{\mathrm{ab}}$ & $8.10^{\mathrm{a}}$ & $26.33^{\mathrm{ab}}$ & $14.78^{\mathrm{b}}$ & $99.14^{\mathrm{ab}}$ & $113.92^{\mathrm{ab}}$ \\
\hline SEm ( \pm$)$ & 1.81 & 2.60 & 3.47 & 0.65 & 0.32 & 0.81 & 0.54 & 6.18 & 6.16 \\
LSD (=0.05) & 5.23 & 7.51 & 10.03 & 1.89 & 0.92 & 2.33 & 1.55 & 17.83 & 17.78 \\
CV, \% & 8.42 & 15.80 & 9.15 & 10.07 & 10.55 & 8.46 & 9.77 & 17.33 & 14.97 \\
Grand mean & 56.86 & 43.54 & 100.40 & 17.19 & 8.02 & 25.21 & 14.55 & 94.27 & 108.82
\end{tabular}

ns, non-significant. HI, harvest index; ET, effective tillers; TGW, thousand grains weight; SSNM, site specific nutrient management; LCC, leaf color chart; FFP, farmers fertility management practice, Rec., Recommended. Means in the column followed by the same letter(s) are not significant different by DMRT at 0.05 level of significance.

FFP had lowest rice grain $P$ uptake that indicates $P$ could also be a rice yield limiting factor in farmers' field. Straw $P$ uptake of different fertility management practices was statistically similar except the FFP. The total $P$ uptake was significantly influenced by fertility management practices; the highest uptake was recorded in LCC-N + SSNM-P \& K which was statistically at par with SSNM and Rec NPK. Significantly lower uptake in 75\% SSNM treatment indicates the nutrient demand of rice was not fulfill by lowering the SSNM dose. Lowest uptake was observed in the FFP followed by Rec. $\mathrm{K}+\mathrm{FFP} \mathrm{N}$ and $\mathrm{P}$.

Grain, straw and total $K$ uptake were highest in LCC-N + SSNM P \& $K$ and lowest in the FFP. Grain $K$ uptake of LCC-N + SSNM P\& K and SSNM were statistically similar while straw $\mathrm{K}$ uptake were similar among LCC-N + SSNM P \& K, SSNM, 75\% SSNM and recommended NPK applied treatments. Similarly, total K uptake in LCC-N + SSNM P 7 K, SSNM and recommended NPK were also at par. Application of recommended $\mathrm{K}$ in FFP increased the $\mathrm{K}$ uptake in grain as well in straw.

\section{POTENTIAL YIELD AND EFFECT OF NUTRIENT MANAGEMENT ON YIELD GAP}

Climatic potential yields were calculated using climatic parameter like daily rainfall, solar radiation, minimum and maximum temperatures and genetic coefficients like thousand grain weight, days to flowering and maturity, duration of tillering and grain filling. The mean simulated $Y_{\max }$ of current rice varieties grown in inner terai of Nepal is around 8.87-9.47 $\mathrm{t} \mathrm{ha}^{-1}$ in main season, with a mean of 9.08 (Regmi, 2003). The mean yield obtained in the LCC-N + SSNM-P \& K treatment was $6.66 \mathrm{t} \mathrm{ha}^{-1}$, thus the rice yield gap (yield gap I) was $0.68 \mathrm{t} \mathrm{ha}^{-1}(9.26 \%)$ indicating the a potentiality of increasing the rice yield in Nepal. The gap would be narrowed if the nutrient would be applied for higher yield target. The yield gap II (based on average yield obtained in the FFP) was calculated as $2.72 \mathrm{t} \mathrm{ha}^{-1}(37.10 \%)$. This wider gap suggests that there is enormous scope to increase rice yield in foot hills and terai region of Nepal. The yield gap III was based on the average yield obtained in LCC-N + SSNM-P \& $K$ and farmers practice was $2.04 \mathrm{t} \mathrm{ha}^{-1}$ indicate that with practice of LCC based $\mathrm{N}$ management and SSNM based $\mathrm{P}$ and $\mathrm{K}$ management only increased the rice yield by $30.67 \%$. The total crop area under rice in Nepal is 1420570 ha. Considering the $80 \%$ of potential yield as the target yield and current average FP yields, rice yield could be increased by $110.04 \%$ and $100.26 \%$ respectively by practicing the SSNM and LCC-N + SSNM-P \& K strategies in Nepal. 
Table 8: Climatic potential yield and yield gaps (t ha-1) with best nutrient management practice of rice at Sunawal, Nawalparasi, Nepal, 2013

\begin{tabular}{|c|c|c|c|c|c|c|}
\hline $\begin{array}{c}\text { Climatic } \\
\text { potential } \\
\text { yield }\left(\mathrm{t} \mathrm{ha}^{-1}\right) \\
(\mathrm{A})\end{array}$ & $\begin{array}{c}80 \% \text { of } \\
\text { climatic } \\
\text { potential yield } \\
\left(\mathrm{t} \mathrm{ha}^{-1}\right)(\mathrm{B})\end{array}$ & $\begin{array}{c}\text { Average yield } \\
\text { obtained in } \\
\text { LCC-N + SSNM- } \\
\text { P \& K (C) }\end{array}$ & $\begin{array}{l}\text { Yield gap I } \\
\left(\mathrm{t} \mathrm{ha}^{-1}\right) \\
(\mathrm{B}-\mathrm{C})\end{array}$ & $\begin{array}{l}\text { Average yield } \\
\text { obtained in } \\
\text { FFP (t ha-1) } \\
\text { (D) }\end{array}$ & $\begin{array}{l}\text { Yield gap II } \\
\left(\mathrm{t} \mathrm{ha}^{-1}\right) \\
(\mathrm{B}-\mathrm{D})\end{array}$ & $\begin{array}{c}\text { Yield gap } \\
\text { III (t ha-1) } \\
\text { (C-D) }\end{array}$ \\
\hline 9.17 & 7.34 & 6.66 & $\begin{array}{c}0.68 \\
(9.26 \%)\end{array}$ & 4.62 & $\begin{array}{c}2.72 \\
(37.10 \%)\end{array}$ & $\begin{array}{c}2.04 \\
(30.67 \%)\end{array}$ \\
\hline
\end{tabular}

Note: SSNM, site specific nutrient management; LCC, leaf color chart; FFP, farmers' fertility practice.

\section{CONCLUSIONS}

SSNM enables to dynamically adjust nutrient use to fill the deficit between the nutrient needs of a high-yielding crop and the nutrient supply from naturally occurring indigenous sources such as soil, crop residues, and manures. Significant increase in grain yield and nutrient uptake because of SSNM were observed. As compared to FFP, SSNM increased the yield by $35.25 \%$ with increased the NPK application by $43.32,17.07$ and $63.70 \mathrm{~kg} \mathrm{ha}^{-1}$. With $25 \%$ lowering the SSNM was also equally effective as recommended NPK by saving of 28.14 and $27.77 \mathrm{~kg} \mathrm{ha}^{-1} \mathrm{~N}$ and P respectively while $14.00 \mathrm{~kg} \mathrm{~K} \mathrm{ha}^{-1}$ was required more than recommended dose. LCC is an effective, low-cost tool that can assist farmers in improving their $\mathrm{N}$ management by adjusting the $\mathrm{N}$ application to match the needs of the crop need and can be used as an important component of SSNM for rice as the yield advantage of $0.31 \mathrm{t} \mathrm{ha}^{-1}$.

\section{ACKNOWLEDGEMENTS}

This research was supported by the Directorate of Research and Extension, Agriculture and Forestry University, Rampur, Chitwan, Nepal.

\section{REFERENCES}

Adhikari, C. Bronson, K. F. Panuallah, G. M. Regmi, A. P. Saha, P. K. Dobermann, A. Olk, D. C. hobbs P. R. and Pasuquin E., 1999. On farm soil $\mathrm{N}$ supply and $\mathrm{n}$ nutrition in the rice-wheat system of Nepal and Bangladesh. Field Crops Research 60: 272-286

AICC, 2014. Krishi Diary 2071. Government of Nepal, Nepal: Agriculture Information and Communication Center, Ministry of Agriculture Development

Bouman, B.A.M. Humphreys, E. Tuong, T. P. and Barker, R., 2006). Rice and water. Advances in Agronomy 92: $187-237$

Buresh, R. J. Witt, C. Ramanathan, S. Chandrasekaran, B. and Rajendran, R., 2005 . Site specific nutrient management: managing N, P, and K for rice. Fert. News 50 (3): 25-37.

Dey, M. M. and Hossain, M.., 1995. Yield potentials of modern rice varieties: an assessment of technological constraints to increase rice production. In Proceedings of the Final Workshop of the Projections and Policy Implications of Medium and Long Term Rice Supply and Demand Project. Beijing, China, 2326/04/1995.

Devkota

Dobermann, A. and White, P. F., 1999.Strategies for nutrient management in irrigated and rainfed lowleand rice. Nutr.Cyl. Agroeco Syst. 53:1-18 
Estefan, G. Sommer, R. and Ryan, J., 2013. Methods of soil, plant, and water analysis: A manual for the West Asia and North Africa region (3rd ed.). Beirut, Lebanon: International Center for Agricultural Research in the Dry Areas.

FAOSTAT., 2012. Food and Agriculture Organization of the United Nations Statistical Database (FAOSTAT) (1990-2010); Trade Map (2011).

FAOSTAT., 2016. FAOSTAT http://faostat.fao.orgAccessed 24 October December 2016

IRRI. 2006. Site-specific nutrient management. http://www.irrri.org/irrc/ssnm Accessed 30 December 2016

Koch, K. and Mengel, K., 1974. The influence of the level of potassium supply to young tobacco plants (Nicotiana tabacum L.) on short-term uptake and utilization of nitrate nitrogen $\left({ }^{15} \mathrm{~N}\right)$. Sci. Food Agric. 25: $165-471$.

Ladha, J. K., Dawe, D. Pathak, H. Padre, A. T. Yadav, R. L. Singh, B. Singh, Y. Singh, Y. Singh, P. Kundu, A. L. Sakal, R. Ram, N. Regmi, A. P. Gami, S. K. Bhandari, A. L. Amin, R. Yadav, C. R. Bhattarai, E. Das, S. Aggarwal, H. P. Gupta, R. K. and Hobbs, P. R., 2003. How extensive are yield declines in long-term rice-wheat experiments in Asia?”. Field Crops Research 81 (2 \& 3): 159-180.

Pampolino, M. F., Manguiat, I. J. Ramanathan, S. Gines, H. C. Tan, P. S. Chi, T. T. N. Rajendran, R. and Buresh, R. J., 2007. Environmental impact and economic benefits of site-specific nutrient management (SSNM) in irrigated rice systems. Agricultural Systems 93: 1-24

Regmi, A. P., 2003. Improving the productivity of rice-wheat system through field specific nutrient management in Nepal. PhD dissertation submitted to University of the Philippines at Los Banos (UPLB), Los Banos, Laguna, Philippines.

Regmi, A. P., Ladha, J. K. Pasuquin, E. Pathak, H. Hobbs, P. R.. Shrestha, L. L. Gharti, D. B. and Duveiller, E., 2002. The role of Potassium in sustaining yields in a long-term rice-wheat experiment in the IndoGangetic plains of Nepal. Biol. Fert. Soils 36:240-247.

Sharma, K. P. Dahal, K. R. and Neupane, K. R., 1991. An introduction to agronomy. Chitwan, Nepal: Institute of Agriculture and Animal Science (IAAS)

Witt, C., Dobermann, A. Abdulrachman, S. Gines, H. C. Wang, G. H. Nagarajun, R. Satawathananont, S. San, T. T. Tan, P. S. Tiem, L. V. Simbahan, G. C. and Olk, D. C., 1999. Internal nutrient efficiencies in irrigated lowland rice of tropical and subtropical Asia. Field Crops Resesearch 63: 113-138.

Yamada, S., M. Osaki, T. Shimano, M. Yamada, M. Ito and Permana, A. T., 2002.Effect of potassium nutrition on current photosynthesized carbon distribution to carbon and nitrogen compounds among rice, soybean, and sunflower. J. Plant Nutr. 25, 1957-1973. 